\title{
SIFAT-SIFAT DINAMIK DARI MODEL INTERAKSI CINTA DENGAN MEMPERHATIKAN DAYA TARIK PASANGAN
}

\author{
AIDA BETARIA \\ Program Studi Matematika, \\ Fakultas Matematika dan Ilmu Pengetahuan Alam, Universitas Andalas, \\ Kampus UNAND Limau Manis Padang, Indonesia. \\ email : aidabetaria31@gmail.com
}

\begin{abstract}
Abstrak. Pada artikel ini dibahas model hubungan cinta antara dua individu dengan memperhatikan daya tarik pasangan. Ada tiga faktor yang diperhatikan dalam model ini, yaitu oblivion (kekuatan melupakan), return (perasaan yang tumbuh karena pasangannya mencintainya), dan instinct (perasaan cinta yang disebabkan oleh daya tarik yang dimiliki pasangannya). Beberapa sifat dinamik dari model dan interpretasinya masing-masing dijelaskan dalam artikel ini.
\end{abstract}

Kata Kunci: Sistem dinamik, model dinamika cinta, daya tarik pasangan, kestabilan

\section{Pendahuluan}

Model dinamika cinta pertama kali digagas oleh Strogatz [4]. Dia menggunakan modelnya tersebut untuk menjelaskan kisah cinta sepasang kekasih, katakanlah Romeo dan Juliet, yang mengalami pasang naik dan pasang surut tanpa henti. Model tersebut kemudian dikembangkan oleh Rinaldi dengan mempertimbangkan faktor oblivion (kekuatan melupakan), return (reaksi terhadap cinta pasangan) dan instinct (daya tarik pasangan) [3]. Model ini beliau kembangkan untuk menjelaskan mengapa dua orang yang pada awalnya sangat berbeda dan tidak saling kenal dapat menjalin sebuah hubungan cinta. Dengan menetapkan semua nilai parameter oblivion, return, dan instinct bernilai positif, Rinaldi kemudian menganalisis sifat-sifat dinamik yang muncul dari modelnya itu.

Model dinamika cinta yang dibahas dalam artikel ini diasumsikan hanya melibatkan dua individu saja, dimana interaksi langsung antar individu diabaikan. Selanjutnya mekanisme cinta yang terjadi dianggap saling bebas dan daya tarik yang dimiliki seseorang bersifat konstan.

Misalkan $x_{1}(t)$ menyatakan ukuran perasaan individu pertama terhadap individu kedua pada waktu $t$ dan $x_{2}(t)$ menyatakan ukuran perasaan individu kedua terhadap individu pertama pada waktu $t$. Nilai $x_{i}(t)$ positif menandakan perasaan positif (mulai dari persahabatan hingga cinta berat), sedangkan nilai $x_{i}(t)$ negatif menandakan perasaan negatif (mulai dari pertentangan hingga benci sekali). Tidak memiliki perasaan apapun ditandai dengan $x_{i}(t)=0$. Model dinamika cinta yang 
dikembangkan oleh Rinaldi diberikan oleh [3]:

$$
\begin{aligned}
& x_{1}^{\prime}(t)=-\alpha_{1} x_{1}(t)+\beta_{1} x_{2}(t)+\gamma_{1} A_{2}, \\
& x_{2}^{\prime}(t)=-\alpha_{2} x_{2}(t)+\beta_{2} x_{1}(t)+\gamma_{2} A_{1} .
\end{aligned}
$$

dimana besarnya kekuatan melupakan $\left(\alpha_{i}\right)$, besarnya reaksi terhadap cinta pasangannya $\left(\beta_{i}\right)$, besarnya reaksi terhadap daya tarik pasangan $\left(\gamma_{i}\right)$ dan besarnya daya tarik pasangannya yang diasumsikan konstanta $\left(A_{i}\right)$.

\section{Analisis Awal}

Pandang sistem persamaan berikut [5] :

$$
\dot{x_{1}}=a x_{1}+b x_{2}, \quad \dot{x_{2}}=c x_{1}+d x_{2},
$$

dimana $x_{i} \equiv x_{i}(t)$ dan $\dot{x}_{i}$ merupakan turunan $x_{i}$ terhadap $t$. Sistem di atas disebut sistem linier homogen dengan koefisien konstan. Persamaan (2.1) dapat ditulis dalam bentuk

$$
\dot{\mathbf{x}}=A \mathbf{x},
$$

dimana

$$
\mathbf{x}=\left[\begin{array}{l}
x_{1}(t) \\
x_{2}(t)
\end{array}\right]
$$

dan

$$
A=\left[\begin{array}{ll}
a & b \\
c & d
\end{array}\right] .
$$

Analog dengan persamaan orde satu linier homogen, solusi persamaan (2.2) dapat ditulis sebagai

$$
\mathbf{x}=\mathbf{v} e^{\lambda t}
$$

dimana

$$
\mathbf{v}=\left[\begin{array}{l}
r \\
s
\end{array}\right]
$$

untuk $r, s$ dan $\lambda$ adalah suatu konstanta. Dengan mensubsitusikan persamaan (2.3) ke (2.2) diperoleh

$$
(\lambda I-A) \mathbf{v}=\mathbf{0},
$$

Oleh karena itu, $\lambda$ adalah nilai eigen dari matriks $A$ dan $\mathbf{v}$ adalah vektor eigen yang bersesuaian dengan nilai eigen $\lambda$.

Persamaan (2.4) selanjutnya dapat ditulis dalam bentuk

$$
\lambda^{2}+p \lambda+q=0,
$$

dimana

$$
p=-(a+d) \text { dan } q=a d-b c .
$$


Potret fasa persamaan (2.2) bergantung pada nilai-nilai eigen matriks $A$. Untuk hal ini, terdapat beberapa kasus nilai eigen yang ditentukan oleh entri-entri matriks $A$, yaitu $a, b, c, d$. Akan ditinjau dua kasus sebagai berikut.

Kasus (i): $b c>0$

Teorema 2.1. [1] Jika bc >0 pada sistem (2.2), maka nilai eigen $\lambda_{1}$ dan $\lambda_{2}$ bernilai riil dengan $\lambda_{2}<\lambda_{1}$.

Bukti. Pandang $p$ dan $q$ pada persamaan (2.5). Karena $b c>0$ maka

$$
\begin{aligned}
p^{2}-4 q & =(-(a+d))^{2}-4(a d-b c) \\
& =a^{2}+d^{2}+2 a d-4 a d+4 b c \\
& =a^{2}+d^{2}-2 a d+4 b c \\
& =(a-d)^{2}+4 b c \\
& >0
\end{aligned}
$$

Karena $p^{2}-4 q>0$, maka nilai eigen $\lambda_{1}$ dan $\lambda_{2}$ untuk sistem (2.2) bernilai riil dengan $\lambda_{2}<\lambda_{1}$.

Untuk kasus $p^{2}>4 q$ dan $p, q>0$ juga berlaku teorema berikut.

Teorema 2.2. [1] Jika $p^{2}>4 q$ dan $p, q>0$, maka $\lambda_{1}$ dan $\lambda_{2}$ bernilai riil dengan $\lambda_{2}<\lambda_{1}<0$.

Bukti. Dari Teorema 2.1 jelas bahwa $p^{2}>4 q$ mengakibatkan $\lambda_{1}$ dan $\lambda_{2}$ bernilai riil dengan $\lambda_{2}<\lambda_{1}$. Karena $p, q>0$, maka

$$
4 q>0 \Longleftrightarrow p^{2}-4 q<p^{2} \Longleftrightarrow \sqrt{p^{2}-4 q}<p \Longleftrightarrow \sqrt{p^{2}-4 q}-p<0 .
$$

Dari hubungan terakhir, jelas bahwa $\lambda_{1}<0$. Jadi $\lambda_{2}<\lambda_{1}<0$.

Kasus (ii): $b c<0$.

(a) $(a-d)^{2}>-4 b c$ dan $a, d<0$.

(b) $(a-d)^{2}<-4 b c$ dan $a, d=0$.

Sistem linier yang akan dibahas pada makalah ini adalah sistem linier yang nonhomogen, dengan persamaan

$$
\dot{\mathbf{x}}(t)=A \mathbf{x}(\mathbf{t})+\mathbf{b},
$$

Teorema 2.3. [2] Persamaan (2.9) dikatakan stabil asimtotik jika dan hanya jika semua nilai eigen dari A mempunyai bagian riil negatif. Dengan kata lain, persamaan tidak stabil jika dan hanya jika terdapat nilai eigen yang bagian riilnya positif.

Bukti. Misalkan $\overline{\mathbf{x}}$ merupakan titik kesetimbangan dari persamaan (2.9). Kemudian tulis $\mathbf{z}=\mathbf{x}-\overline{\mathbf{x}}$. Karena $\overline{\mathbf{x}}$ merupakan suatu vektor konstan, maka $\dot{\mathbf{z}}=\dot{\mathbf{x}}$. 
Jadi,

$$
\begin{aligned}
\dot{\mathbf{x}}=A \mathbf{x}+\mathbf{b} & \Leftrightarrow \dot{\mathbf{x}}=A(\mathbf{z}+\overline{\mathbf{x}})+\mathbf{b} \\
& \Leftrightarrow \dot{\mathbf{z}}=A \mathbf{z}+A \overline{\mathbf{x}}+\mathbf{b} .
\end{aligned}
$$

Karena $\overline{\mathbf{x}}$ merupakan titik kesetimbangan, berlaku $A \overline{\mathbf{x}}+\mathbf{b}=\mathbf{0}$, sehingga

$$
\dot{\mathbf{z}}=A \mathbf{z} .
$$

Solusi persamaan (2.12) berdasarkan penjelasan sebelumnya, yaitu

$$
\mathbf{z}=\mathbf{v} e^{\lambda t},
$$

dimana $\lambda$ adalah nilai eigen dari $A$ dan $\mathbf{v}$ adalah vektor eigen yang bersesuaian dengan nilai eigen. Nilai eigen dapat ditulis dengan

$$
\lambda=\mu+i \omega,
$$

dimana $i=\sqrt{-1}$ dan $\mu, \omega$ bernilai riil. Jelas bahwa $\mathbf{z}=\mathbf{v} e^{(\mu+i \omega) t}=\mathbf{v}\left(e^{\mu t} e^{i \omega t}\right) \rightarrow \mathbf{0}$ untuk $t \rightarrow \infty$ jika dan hanya jika $\mu<0$, atau dengan kata lain bagian riil dari nilai eigen $\lambda$ bernilai negatif. Karena $\mathbf{z}=\mathbf{x}-\overline{\mathbf{x}}$ dan $\overline{\mathbf{z}}=\mathbf{0}$, maka pernyataan terakhir menyatakan bahwa $\mathbf{x} \rightarrow \overline{\mathbf{x}}$ jika dan hanya jika semua nilai eigen dari $A$ mempunyai bagian riil yang negatif.

Lebih lanjut, $\|\mathbf{z}\|=\left\|\mathbf{v} e^{\lambda t}\right\|=\|\mathbf{v}\| e^{\lambda t} \rightarrow \infty$ ketika $t \rightarrow \infty$ jika dan hanya jika $\mu>0$. Karena $\|\mathbf{z}\|=\|\mathbf{x}-\overline{\mathbf{x}}\| \leqslant\|\mathbf{x}\|+\|\overline{\mathbf{x}}\|$, maka berlaku $\|\mathbf{x}\| \rightarrow \infty$ ketika $t \rightarrow \infty$ jika dan hanya jika terdapat nilai eigen yang mempunyai bagian riil positif.

\section{Sifat-Sifat Dinamik}

Persamaan (1.1) dapat ditulis ulang dalam bentuk matriks sebagai berikut:

$$
\dot{\mathbf{x}}=A \mathbf{x}+\mathbf{b},
$$

dimana

$$
A=\left[\begin{array}{cc}
-\alpha_{1} & \beta_{1} \\
\beta_{2} & -\alpha_{2}
\end{array}\right], \quad \mathbf{b}=\left[\begin{array}{l}
A_{2} \\
A_{1}
\end{array}\right] .
$$

Pada artikel ini, akan dibahas tiga sifat dinamik sederhana dari sistem (3.1).

Sifat 3.1. Sistem (3.1) tidak memiliki potret fasa pusat jika

$$
\beta_{1} \beta_{2}>0 \text { atau } \beta_{1} \beta_{2}<0 .
$$

Bukti. Perhatikan bawa $\beta_{1} \beta_{2}>0$ atau $\beta_{1} \beta_{2}<0$ memenuhi premis pada Teorema 2.2. Jadi nilai eigen $\lambda_{1}$ dan $\lambda_{2}$ dari matriks $A$ bernilai riil, sehingga hal tersebut bukan merupakan kasus (ii(b)). Akibatnya sistem (3.1) tidak mungkin memiliki potret fasa pusat.

Interpretasi. Kisah cinta yang dimodelkan pada sistem (3.1), dengan nilai-nilai parameter yang memenuhi (3.3) tidak mengalami proses siklik, artinya perasaan cinta mereka akan naik atau turun ke suatu nilai. 
Sifat 3.2. Sistem (3.1) stabil asimtotik jika memenuhi hubungan

$$
\alpha_{1} \alpha_{2}-\beta_{1} \beta_{2}>0 \text { atau } \beta_{1} \beta_{2}>0 \text { dengan }\left(-\alpha_{1}+\alpha_{2}\right)>-4 \beta_{1} \beta_{2}
$$

Bukti. Nilai eigen dari matriks $A$ adalah

$$
\lambda_{1}=\frac{-p+\sqrt{p^{2}-4 q}}{2}, \quad \lambda_{2}=\frac{-p-\sqrt{p^{2}-4 q}}{2}
$$

dimana $p=-\left(-\alpha_{1}-\alpha_{2}\right)=\alpha_{1}+\alpha_{2}$ dan $q=\left(-\alpha_{1}\right)\left(-\alpha_{2}\right)-\beta_{1} \beta_{2}=\alpha_{1} \alpha_{2}-\beta_{1} \beta_{2}$. Diketahui bahwa $\alpha_{i}>0$ sehingga $p>0$. Selanjutnya hubungan (3.4) mengakibatkan $p^{2}-4 q>0$ dan $q>0$. Dengan demikian, berdasarkan Teorema 2.2, nilai eigen $\lambda_{1}$ dan $\lambda_{2}$ bernilai riil dengan $\lambda_{2}<\lambda_{1}<0$. Akibatnya berdasarkan Teorema 2.3, sistem (3.1) stabil asimtotik.

Interpretasi. Untuk kasus $\alpha_{1} \alpha_{2}-\beta_{1} \beta_{2}>0$, perasaan kedua individu terbatas jika rata-rata (geometrik) dari koefisien reaksi terhadap perasaan cinta pasa-ngannya $\left(\sqrt{\beta_{1} \beta_{2}}\right)$ lebih kecil daripada rata-rata (geometrik) kekuatan melupakan $\sqrt{\alpha_{1} \alpha_{2}}$. Jika hal tersebut tidak berlaku, maka perasaan yang dimiliki oleh kedua individu tersebut menjadi tidak terbatas.

Sifat 3.3. Titik kesetimbangan $\overline{\boldsymbol{x}}=\left(\bar{x}_{1}, \bar{x}_{2}\right)$ dari sistem (3.1) bernilai positif yaitu $\bar{x}_{i}>0$ untuk $i=1,2$, jika

$$
\beta_{1} \beta_{2}<\alpha_{1} \alpha_{2}, \alpha_{2} A_{2}+\beta_{1} A_{1}>0 \text { dan } \alpha_{1} A_{1}+\beta_{2} A_{2}>0 .
$$

Bukti. Titik kesetimbangan $\overline{\mathrm{x}}=\left(\bar{x}_{1}, \bar{x}_{2}\right)$ dari sistem (3.1) melalui penyelesaian sistem persamaan

$$
\begin{aligned}
& -\alpha_{1} x_{1}+\beta_{1} x_{2}+A_{2}=0, \\
& -\alpha_{2} x_{2}+\beta_{2} x_{1}+A_{1}=0 .
\end{aligned}
$$

yang diberikan oleh

$$
x_{1}=\bar{x}_{1}=\frac{\alpha_{2} A_{2}+\beta_{1} A_{1}}{\alpha_{1} \alpha_{2}-\beta_{1} \beta_{2}}, \quad x_{2}=\bar{x}_{2}=\frac{\alpha_{1} A_{1}+\beta_{2} A_{2}}{\alpha_{1} \alpha_{2}-\beta_{1} \beta_{2}} .
$$

Jelas bahwa (3.6) bernilai positif jika $\alpha_{1} \alpha_{2}-\beta_{1} \beta_{2}>0, \alpha_{2} A_{2}+\beta_{1} A_{1}>0$, dan $\alpha_{1} A_{1}+\beta_{2} A_{2}>0$.

Interpretasi. Dua individu yang awalnya bertemu belum memiliki perasaan apapun, namun seiring dengan berjalannya waktu, kedua individu tersebut akan membentuk perasaan positif $\left(x_{i}(t)>0\right)$ menuju ke suatu nilai kesetimbangan yang positif jika memenuhi (3.5).

\section{Kesimpulan dan Saran}

Sifat-sifat dinamik dari model dinamika cinta dengan memperhatikan daya tarik pasangan telah dibahas dalam artikel ini. Selain itu juga telah dijelaskan interpretasi interaksi cinta yang terjadi berdasarkan sifat-sifat tersebut. Untuk penelitian selanjutnya, kajian serupa dalam artikel ini juga dapat dikembangkan pada model dinamika cinta segitiga. 


\section{Ucapan Terimakasih}

Terimakasih untuk semua pihak yang telah membantu dalam penyelesaian penulisan artikel ini.

\section{Daftar Pustaka}

[1] Boyce, W. E dan Prime. 2012. Elementary Differential Equations. 10th Edition. John Wiley Sons, New York.

[2] Luenberger. D.G. 1979. Introduction to Dynamic Systems. New York: John Wiley and Sons Inc.

[3] Rinaldi, Sergio. 1998. Love Dynamics: The Case of Linier Couples. Applied Mathematics and Computation 95: 181 - 192.

[4] Strogatz, H Steven. 1988. Love Affairs and Differential Equations. Mathematic Magazine 61 : 35.

[5] Finizio, Ladas dan Widiarti, S. 1998. Persamaan Diferensial Biasa dengan Penerapan Modern. Edisi ke-2. Jakarta: Erlangga. 